\title{
PENGARUH EKOENZIM TERHADAP \\ KUALITAS AIR DALAM PEMBESARAN IKAN LELE (Clarias gariepinus)
}

The Effect Of Ekoenzim On

Quality Of Water In The Lele Fish Power (Clarias gariepinus)

\author{
Arnita Ayu Kusumawati, Djoko Suprapto*), Haeruddin \\ Program Studi Manajemen Sumberdaya Perairan, Departemen Sumberdaya Akuatik \\ Fakultas Perikanan dan Ilmu Kelautan, Universitas Diponegoro \\ J1. Prof. Sudarto, SH,Tembalang, Semarang, Jawa Tengah - 50275, Telp/Fax. +62247474698 \\ Email : arnitakusumawati22@gamil.com
}

\begin{abstract}
ABSTRAK
Kualitas air merupakan salah satu faktor penting dalam budidaya, walaupun ikan lele mampu bertahan hidup dalam kondisi kualitas air yang buruk namun keadaan itu akan berpengaruh pada pertumbuhannya. Pada penelitian ini bertujuan untuk mengetahui pengaruh ekoenzim terhadap kualitas air pada pembesaran ikan lele. Penelitian dilakukan pada bulan April - Mei 2018 di Laboratorium Pengelolaan Sumberdaya Ikan dan Lingkungan, Fakultas Perikanan dan Ilmu Kelautan, Universitas Diponegoro,Semarang. Metode yang digunakan pada penelitian ini adalah metode eksperimen di laboratorium dengan menggunakan desain penelitian yaitu rancangan acak lengkap (RAL). Penelitian ini dilakukan dengan menggunakan 4 perlakuan yaitu kontrol, $0,1 \mathrm{ml} / \mathrm{L}, 0,5 \mathrm{ml} / \mathrm{L}$, dan $1 \mathrm{ml} / \mathrm{L}$ dengan 3 pengulangan. Pada penelitian ini menggunakan analisis data one way Anova dengan menggunakan data konsentrasi amoniak dan nitrit sedangkan konsentrasi DO, pH, temperature , dan Pertubuhan menggunakan analisis deskriptif. Hasil analisis data yang telah dilakukan menunjukan bahwa tidak ada perbedaan rata-rata hasil konsentrasi amoniak dan nitrit dengan konsentrasi ekoenzim yang berbeda. Jadi pemberian ekoenzim di media pemeliharaan ikan lele menunjukan hasil yang baik untuk proses budidaya namun masih kurang baik untuk pertumbuhan ikan lele tersebut, karena didapatkan hasil pertumbuhan ikan lele cenderung lambat.
\end{abstract}

Kata Kunci : Ikan Lele, Ekoenzim, Kualitas Air

\begin{abstract}
Water quality is an important factor in cultivation, although catfish are able to survive under poor water quality conditions but the situation will affect its growth. In this study aims to determine the effect of eczymes on water quality in the enlargement of catfish. The study was conducted in April - May 2018 at the Fish and Environmental Resource Management Laboratory, Faculty of Fisheries and Marine Sciences, Diponegoro University, Semarang. The method used in this study is an experimental method in the laboratory using a research design that is a completely randomized design (CRD). This research was conducted by using 4 treatments, namely control, $0.1 \mathrm{ml} / \mathrm{L}, 0.5 \mathrm{ml} / \mathrm{L}$, and $1 \mathrm{ml} / \mathrm{L}$ with 3 repetitions. In this study used one way Anova data analysis using ammonia concentration data and nitrite concentration while DO, $\mathrm{PH}$, temperature, and Growth using descriptive analysis. The results of the data analysis that has been carried out show that there is no difference in the average yield of the concentration of ammonia and nitrite with different eczene concentrations. So ekoenzim peberian in catfish breeding media showed good results for the cultivation process but still not good for the growth of catfish, because the results obtained growth of catfish tend not slow.
\end{abstract}

Keywords: Catfish, Ekoenzim, Water Quality

*) Penulis penanggungjawab

\section{PENDAHULUAN}

Indonesia merupakan Negara yang penduduknya tergolong berjumlah besar. Peningkatan jumlah populasi penduduk di Indonesia menyebabkan tingkat kebutuhan konsumsi pangan meningkat, salah satunya yaitu kebutuhan akan protein. Protein dapat didapatkan dari berbagai sumber makanan salah satunya yaitu yang terdapat pada ikan. Usaha budidaya ikan banyak berkembang di Indonesia belakangan ini, salah satunya adalah usaha pembudidayaan ikan lele.

Dalam usaha budidaya ikan, kualitas air merupakan salah satu faktor penting yang berpengaruh terhadap kelangsungan hidup ikan yang dibudidayakan. Menurut Mulyanto (1992) dalam Tania (2016), bahwa kondisi air sebagai media hidup biota air, harus disesuaikan dengan kondisi optimal bagi biota yang dipelihara. Kualitas air

${ }^{\odot}$ Copyright by Management of Aquatic Resources (MAQUARES) 
tersebut meliputi kualitas fisika, kimia dan biologi. Faktor fisika misalnya suhu, kecerahan dan kedalaman. Faktor kimia diantaranya $\mathrm{pH}, \mathrm{DO}, \mathrm{CO} 2$ dan $\mathrm{NH}_{3}-\mathrm{N}$.

Untuk menjaga kualitas air pada budidaya ikan lele harus dilakukannya rekayasa manusia. Sudah banyak peneliti yang melakukan upaya untuk menjaga kualitas air yaitu salah satunya dengan mengkombinasikan pakan ikan karena sisa hasil pencernaan mampu mempengaruhi kualitas air, Selain di pakan kita harus juga mampu merekayasa langsung pada perairan budidayanya. Permasalahan tersebutlah yang melatarbelakangi peneliti untuk melakukan penelitian dengan menambahkan ekoenzim kedalam air budidaya ikan lele, sehingga dapat diketahui pengaruh ekoenzim tersebut terhadap kualitas airnya. Peneliti memilih rekayasa dengan penambahan ekoenzim karena diektahui ekoenzim ini adalah suatu larutan yang berfungsi untuk menjernihkan air. Menurut Dewi et al., (2015) Fungsi ekoenzim adalah sebagai berikut : Dapat membantu pertumbuhan tanaman organic, Membantu ternak tetap sehat, Membersihkan saluran, Menjernihkan air, Mengurangi sampah, sebagai sabun pencuci piring. Maka dari itu penelitian ini bertujuan untuk mengetahui pengaruh ekoenzim terhadap kualitas air dalam pembesaran ikan lele.

\section{MATERI DAN METODE PENELITIAN}

Penelitian ini dilaksanakan pada bulan April - Mei 2018. Kegiatan penelitian ini bertempat di Laboratorium Pengelolaan Sumberdaya Ikan dan Lingkungan, Fakultas Perikanan dan Ilmu Kelautan, Universitas Diponegoro,Semarang.

\section{a. Alat Dan Bahan}

Alat yang digunakan adalah Water Quality Checker, spektrofotometer uv-visible, dan akuarium ukuran 30x20x20 $\mathrm{cm}$,sedangkan bahan yang digunakan yaitu ekoenzim, Ikan Lele, reagen amoniak, dan reagen nitrit.

\section{b. Metode}

Metode penelitian yang dilakukan adalah penelitian eksperimen di laboratorium, Sesuai dengan tujuan penelitian ini yaitu untuk mengetahui konsentrasi amoniak, nitrit, $\mathrm{DO}, \mathrm{pH}$, dan temperatur dalam media pemeliharaan, serta mengetahui perubahan kualitas air setelah pemberian enzim pada wadah pemeliharan ikan lele . Variabel penelitian yang telah ditentukan terdiri dari 2 (dua) variabel yaitu variabel utama dan penunjang. Variabel utama adalah senyawa amoniak dan nitrit. Variabel penunjang antara lain oksigen terlarut, $\mathrm{pH}$, dan temperatur. Desain penelitian yang peneliti telah lakukan dalam penelitian ini adalah berdasarkan rancangan acak lengkap (RAL), dengan empat perlakuan yaitu dengan tanpa ekoenzim (kontrol), diberi ekoenzim $1 \mathrm{mg} / \mathrm{L}$, diberi ekoenzim $10 \mathrm{mg} / \mathrm{L}$, dan diberi ekoenzim $100 \mathrm{mg} / \mathrm{L}$. Dalam uji penelitian di lakukan 3x pengulangan dengan menggunakan 12 akuarium. Pada penelitian ini menggunakan ikan uji yaitu benih ikan lele. Pemberian pakan pada ikan lele dilakukan 2x dalam sehari yaitu pagi hari pukul 09.00 WIB dan sore hari pukul 16.00 WIB. Penelitian pendahuluan ini dilakukan selama seminggu dengan melakukan uji amoniak dan nitrit. Kemudian hasil yang terbaik akan digunakan untuk kisaran dosis dalam penilitian utama. Analisis data dilakukan dengan menggunakan program SPSS Statistik 16 dengan uji statistik yang digunakan adalah statistik parameterik berupa one way ANOVA.

\section{HASIL DAN PEMBAHASAN}

\section{Hasi Pengukuran}

Berdasarkan hasil penelitian yang telah dilakukan dapat diketahui hasil berikut ini:

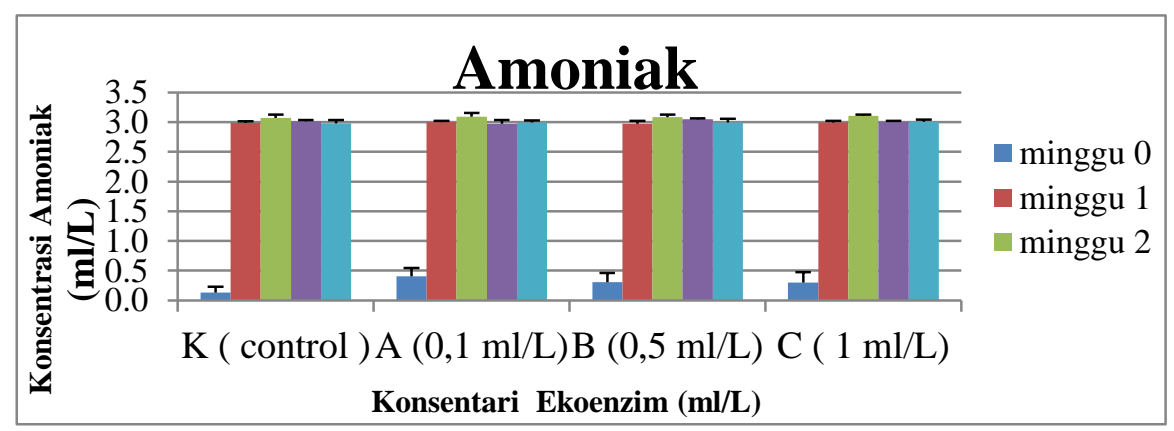

Tabel 1. Hasil one way ANOVA Pengukuran Amoniak Selama Penelitian

\begin{tabular}{lccccc}
\hline Sumber Keragaman & Jumlah Kuadrat & derajat bebas & Rata-rata kuadrat & F & Sig. \\
\hline &, 027 & 3 &, 009 &, 007 &, 999 \\
Antar grup & 72,388 & 56 & 1,293 & \\
Dalam grup & 72,415 & 59 & & \\
Total & & & & \\
\hline
\end{tabular}




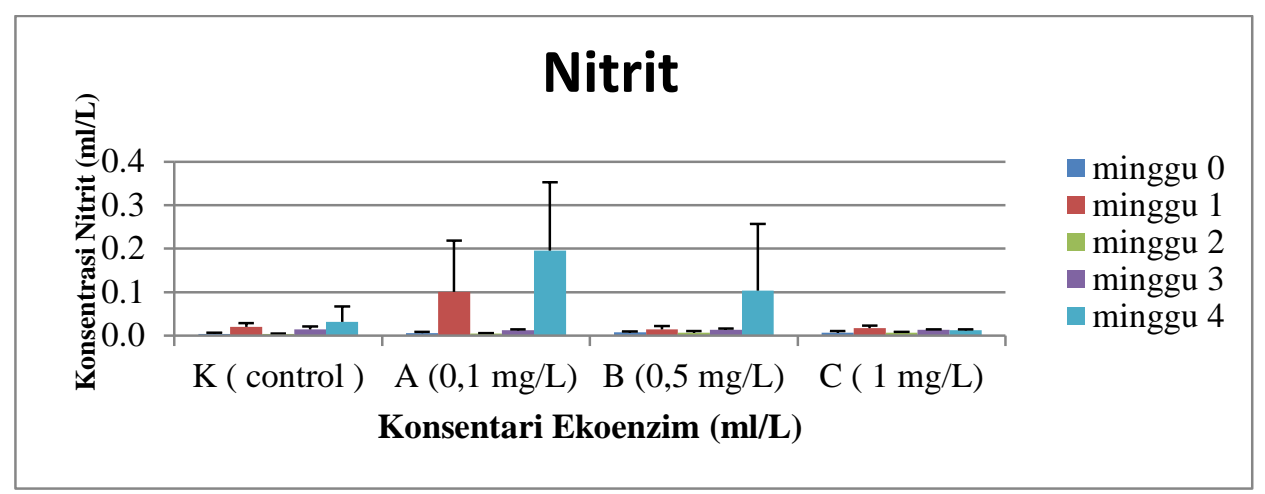

Tabel 3. Hasil One way ANOVA Pengukuran Nitrit Selama Penelitian

\begin{tabular}{|c|c|c|c|c|c|c|c|c|c|c|c|c|c|}
\hline \multicolumn{2}{|c|}{ Sumber Keragaman } & \multicolumn{3}{|c|}{ Jumlah Kuadrat } & \multicolumn{3}{|c|}{ derajat bebas } & \multicolumn{2}{|c|}{ Rata-rata kuadrat } & \multicolumn{2}{|c|}{$\mathrm{F}$} & Sig. & \\
\hline \multicolumn{2}{|l|}{ Antar grup } & \multicolumn{3}{|c|}{,026 } & \multicolumn{2}{|c|}{3} & & \multicolumn{2}{|c|}{,009 } & \multicolumn{2}{|c|}{2,043} & 118 & \\
\hline \multicolumn{2}{|l|}{ Dalam grup } & \multicolumn{3}{|c|}{,235 } & \multicolumn{2}{|c|}{56} & \multicolumn{3}{|c|}{,004 } & & & & \\
\hline Total & & \multicolumn{3}{|c|}{,261 } & \multicolumn{2}{|c|}{59} & & & & & & & \\
\hline \multicolumn{14}{|c|}{ Tabel 3. Hasil Pengukuran Panjang Total } \\
\hline \multirow{2}{*}{$\begin{array}{c}\text { Minggu } \\
\text { ke- }\end{array}$} & \multirow{2}{*}{ Ikan uji } & \multicolumn{12}{|c|}{ Panjang Ikan $(\mathrm{cm})$} \\
\hline & & K1 & $\mathrm{K} 2$ & $\mathrm{~K} 3$ & A1 & A2 & A3 & $\mathrm{B} 1$ & $\mathrm{~B} 2$ & B3 & $\mathrm{C} 1$ & $\mathrm{C} 2$ & $\mathrm{C} 3$ \\
\hline \multirow{4}{*}{0} & Ikan 1 & 5,2 & 5,7 & 5,5 & 5,6 & 5,6 & 5,2 & 5,3 & 5,3 & 5,5 & 5,8 & 5,3 & 5,3 \\
\hline & Ikan 2 & 5,6 & 5,1 & 5,4 & 5,5 & 5,8 & 5,2 & 5,3 & 5,7 & 5,5 & 5,4 & 5,5 & 5,5 \\
\hline & Ikan 3 & 5,2 & 5,8 & 5,3 & 5,7 & 5,8 & 5,1 & 5,5 & 5,6 & 5,4 & 5,4 & 5,2 & 5,3 \\
\hline & Ikan 4 & 5,3 & 5,4 & 5,3 & 5,4 & 5,2 & 5,7 & 5,2 & 5,2 & 5,7 & 5,5 & 5,5 & 5,4 \\
\hline \multirow{4}{*}{4} & Ikan 1 & 6,2 & 6,8 & 6,3 & 5,9 & 6,4 & 6,5 & 7,3 & 7,6 & 6,8 & 6,5 & 6,4 & 6,5 \\
\hline & Ikan 2 & 6,9 & 7,1 & 6,7 & 6,3 & 7,8 & 7,3 & 7,8 & 7,3 & 7,0 & 6,5 & 7,1 & 6,5 \\
\hline & Ikan 3 & 7,2 & 7,4 & 6,7 & 7,6 & 7,5 & 6,8 & 6,3 & 7,6 & 6,4 & 7,1 & 6,3 & 7,8 \\
\hline & Ikan 4 & 6,9 & 6,4 & 7,0 & 6,5 & 7,3 & 6,4 & 7,0 & 8,0 & 7,0 & 6,9 & 6,3 & 8,0 \\
\hline
\end{tabular}

Tabel 4. Hasil Pengukuran Bobot Ikan

\begin{tabular}{|c|c|c|c|c|c|c|c|c|c|c|c|c|c|}
\hline \multirow{2}{*}{$\begin{array}{c}\text { Minggu } \\
\text { ke- }\end{array}$} & \multirow{2}{*}{$\begin{array}{c}\text { Ikan } \\
\text { uji }\end{array}$} & \multicolumn{12}{|c|}{ Bobot Ikan ( gram ) } \\
\hline & & $\mathrm{K} 1$ & $\mathrm{~K} 2$ & K3 & A1 & A2 & A3 & B1 & $\mathrm{B} 2$ & B3 & $\mathrm{C} 1$ & $\mathrm{C} 2$ & $\mathrm{C} 3$ \\
\hline \multirow{4}{*}{0} & Ikan 1 & 1,14 & 1,13 & 1,21 & 1,16 & 1,13 & 1,16 & 1,22 & 1,17 & 1,16 & 1,20 & 1,14 & 1,12 \\
\hline & Ikan 2 & 1,15 & 1,15 & 1,15 & 1,17 & 1,15 & 1,18 & 1,15 & 1,12 & 1,18 & 1,19 & 1,14 & 1,14 \\
\hline & Ikan 3 & 1,20 & 1,14 & 1,12 & 1,19 & 1,15 & 1,12 & 1,12 & 1,15 & 1,12 & 1,14 & 1,15 & 1,14 \\
\hline & Ikan 4 & 1,11 & 1,17 & 1,14 & 1,12 & 1,14 & 1,14 & 1,12 & 1,15 & 1,12 & 1,13 & 1,12 & 1,12 \\
\hline \multirow{4}{*}{4} & Ikan 1 & 2,62 & 2,17 & 4,21 & 1,92 & 3,89 & 4,01 & 2,34 & 3,98 & 2,12 & 2,84 & 2,12 & 2,93 \\
\hline & Ikan 2 & 2,16 & 2,41 & 2,14 & 2,91 & 4,17 & 4,12 & 2,12 & 3,12 & 2,10 & 4,34 & 2,45 & 2,89 \\
\hline & Ikan 3 & 3,01 & 2,16 & 3,05 & 2,34 & 3,01 & 2,01 & 2,56 & 2,18 & 2,56 & 2,98 & 2,01 & 2,78 \\
\hline & Ikan 4 & 2,16 & 2,20 & 2,61 & 3,00 & 2,24 & 2,12 & 3,01 & 3,56 & 2,34 & 2,88 & 2,32 & 4,32 \\
\hline
\end{tabular}

\section{PEMBAHASAN}

\section{Konsentrasi Amoniak (NH3-N)}

Berdasarkan hasil yang didapat dalam penelitian selama 4 minggu dengan 3 pengulangan, nilai konsentrasi amoniak (NH3-N) pada konsentrasi (0,1 mg/L) selama 4 minggu dengan 3 kali pengulangan berkisar 0,242-3,150 mg/L, pada konsentrasi $(0,5 \mathrm{mg} / \mathrm{L})$ berkisar 0,170-3,135 mg/L, pada konsentrasi (1 mg/L) berkisar 0,169 - 3,123mg/L, dan nilai konsentrasi amoniak pada kontrol yaitu berkisar 0,016- 3,132 mg/L. Menurut Hermawan et al.,(2012), menyatakan bahwa ikan lele masih dapat hidup pada kisaran amoniak 0,5 - 3,8 mg/L. Hal ini diperkuat oleh Hastuti dan Subandiyono (2015) bahwa konsentrasi ammonia yang masih aman untuk ikan lele adalah 5,70 mg/L. Jadi hasil amoniak selama penelitian berlangsung masih memenuhi kelayakan dan baik untuk pertumbuhan ikan lele. Diketahui nilai konsentrasi amoniak sudah melebihi baku mutu untuk perikanan yang telah ditetapkan, namun dalam kondisi ini ikan lele tetap hidup. Hal ini disebabkan oleh keseimbangan nilai temperatur berkisar $25-26^{\circ} \mathrm{C}$ dan nilai pH berkisar 5-6 , karena persentase amoniak di pengaruhi oleh beberapa faktor seperti temperature dan $\mathrm{pH}$. Semakin tinggi temperatur dan $\mathrm{pH}$ makin tinggi nilai amoniak. Hal ini diperkuat oleh Tancung dan Kordi (2007), makin tinggi temperatur dan $\mathrm{pH}$ air makin tinggi pula presentase konsentrasi amoniak. 
Hasil uji analisis one way Anova, menunjukkan bahwa tidak ada perbedaan rata-rata antara hasil konsentrasi amoniak dengan menggunaan konsentrasi ekoenzim berbeda. Sehingga perbedaan konsentrasi ekoenzim menghasilkan amoniak yang rata-rata hampir sama nilainya. Jadi pemberian ekoenzim di media pemeliharaan ikan lele dengan konsentrasi berbeda tidak menghasilkan rata-rata konsentrasi amoniak yang berbeda pula, namun tetap membuat hasil amoniak yang masih baik untuk budidaya ikan lele.

\section{Konsentrasi Nitrit (NO2)}

Berdasarkan hasil yang didapat dalam penelitian selama 4 minggu dengan 3 pengulangan, nilai konsentrasi nitrit pada konsentrasi $(0,1 \mathrm{mg} / \mathrm{L})$ berkisar $0,0026-0,3051 \mathrm{mg} / \mathrm{L}$, pada konsentrasi $(0,5 \mathrm{mg} / \mathrm{L})$ berkisar $0,0057-0,2811 \mathrm{mg} / \mathrm{L}$, pada konsentrasi (1 mg/L) berkisar 0,0024- 0,0241 mg/L, dan nilai konsentrasi nitrit pada kontrol yaitu berkisar 0,0070$0,0727 \mathrm{mg} / \mathrm{L}$. Hasil tersebut menunjukkan bahwa nilai konsentrsi nitrit ada yang melebihi baku mutu dan ada juga yang tidak melebihi batas ambang baku mutu. Menurut Peraturan Pemerintah No. 82 Tahun 2001 baku mutu air kelas III untuk kegiatan perikanan, kadar maksimal untuk parameter nitrit di dalam air baku 0,06 mg/L. Menurut Effendi (2003), menyatakan bahwa nilai nitrit hal tersebut menyebabkan berkurangnya kemampuan darah dalam mengikat oksigen dan perairan menjadi toksik. Menurut Tancung dan Kordi (2007), mekanisme toksitas dari nitrit adalah pengaruhnya terhadap transpor oksigen dalam darah dan kerusakan jaringan. Senyawa nitrit yang berlebih dalam suatu perairan akan menyebabkan menurunnya kemampuan darah organisme perairan untuk mengikat O2, Hal ini diperkuat oleh Iswandi et al., (2016) menyatakan bahwa kadar nitrit yang direkomendasikan untuk budidaya ikan lele adalah $<1 \mathrm{mg} / \mathrm{L}$.

Hasil uji analisis one way Anova, menunjukkan bahwa tidak ada perbedaan rata-rata antara hasil konsentrasi nitrit dengan menggunaan konsentrasi ekoenzim berbeda. Sehingga perbedaan konsentrasi ekoenzim menghasilkan nitrit yang rata-rata hampir sama nilainya. Jadi pemberian ekoenzim di media pemeliharaan ikan lele dengan konsentrasi berbeda tidak menghasilkan rata-rata konsentrasi nitrit yang berbeda pula, namun tetap membuat hasil nitrit yang masih baik untuk budidaya ikan lele.

\section{Temperatur Air}

Pengukuran temperatur air dilakukan 2 kali dalam sehari dimana pada pagi hari pukul 09.00 dan sore hari pukul 16.00. berdasarkan hasil pengukuran yang dilakukan, temperatur air minggu pertama pada pagi hari memiliki kisaran $25,0-26,4^{\circ} \mathrm{C}$ dari semua konsentrasi. Sedangkan temperatur air pada saat sore hari memiliki kisaran $25,0-26,1^{\circ} \mathrm{C}$. Selanjutnya temperatur air minggu kedua pada pagi hari memiliki kisaran $25,5-26,4^{\circ} \mathrm{C}$ dan temperatur air pada saat sore hari memiliki kisaran $25,1-26,3^{\circ} \mathrm{C}$. Temperatur air pada minggu ketiga pada pagi hari berkisar $25,1-26,3^{\circ} \mathrm{C}$ dan sore hari berkisar $25,1-26,3^{\circ} \mathrm{C}$ dan temperatur air pada minggu keempat pada pagi hari berkisar $25,5-26,3^{\circ} \mathrm{C}$ dan sore hari berkisar $25,2-26,0^{\circ} \mathrm{C}$.

Berdasarkan hasil pengu pengukuran selama 4 minggu, temperatur air menunjukkan hasil relatif tetap namun berfluktuasi dan sesuai dengan baku mutu sehingga temperatur air ini sangat layak untuk kehidupan organisme perairan. Menurut Effendi (2003), kisaran temperatur air yang optimum bagi kehidupan organisme adalah $<40^{\circ} \mathrm{C}$. Temperatur ideal adalah $25-30^{\circ} \mathrm{C}$, temperatur yang terlalu tinggi akan merusak proses dengan mencegah aktivitas enzim dalam sel. Peningkatan $1{ }^{\circ} \mathrm{C}$. Temperatur dari kisaran ideal dapat menyebabkan penurunan efisensi pengolahan, sehingga terjadi peningkatan daya racun dari suatu polutan organisme akuatik. Menurut Hermawan et al., (2012) menyatakan bahwa kisaran suhu yang cocok untuk budidaya ikan lele adalah pada kisaran suhu sebesar 23-30 ${ }^{\circ}$ C. Jadi berdasarkan penelitian yang telah dilakukan kisaran suhu selama pemberian ekoenzim pada pemeliharaan ikan lele masih memenuhi kelayakan dan cukup baik untuk budidaya ikan lele .

\section{Derajat Keasaman (pH)}

$\mathrm{pH}$ merupakan faktor lingkungan utama dalam perkembangbiakkan organisme. Pengukuran $\mathrm{pH}$ dilakukan 2 kali dalam sehari, yaitu pada pagi hari jam 09.00 dan sore hari pukul 16.00. berdasarkan hasil pengukuran yang dilakukan didapatkan nilai pH pada minggu pertama pagi hari berkisar 5,85-6,71 dan sore hari berkisar 5,71-6,40. Selanjutnya pada minggu kedua nilai $\mathrm{pH}$ pada pagi hari berkisar 5,90-6,86 dan sore hari berisar 5,91-6,89. Selanjutnya nilai pH pada minggu ketiga pagi hari berkisar 5,85-6,75 dan sore hari berkisar 5,95-6,81. Selanjutnya nilai pH minggu keempat pagi hari berkisar 5,85-6,80 dan sore hari berkisar 5,96-6,89.

Berdasarkan hasil pengukuran $\mathrm{pH}$ selama 4 minggu, nilai $\mathrm{pH}$ relatif namun berfluktuatif dan sesuai dengan baku mutu. Menurut Rachmawati et al., (2015), menyatakan mikroorganisme umumnya memiliki kondisi pertumbuhan dengan $\mathrm{pH}$ 4-9,5. Senyawa amonium yang dapat terionisasi banyak ditemukan pada perairan yang memiliki $\mathrm{pH}$ rendah. Amonium bersifat lebih toksik, namun pada suasana $\mathrm{pH}$ tinggi, lebih banyak ditemukan amoniak yang tidak terionisasi dan bersifat toksik. Menurut Menurut Hermawan et al., (2012) menyatakan bahwa nilai pH yang optimum untuk buidaya ikan lele berkisar antara 6 -8,5. Jadi berdasarkan penelitian yang telah dilakukan kisaran pH selama pemberian ekoenzim pada pemeliharaan ikan lele masih memenuhi kelayakan dan cukup baik untuk budidaya ikan lele .

\section{Dissolved oxygen (DO)}

Oksigen merupakan faktor pembatas, sehingga bila ketersediaannya didalam air tidak mencukupi kebutuhan biota budidaya, maka segala aktivitas biota akan terhambat. Kebutuhan oksigen pada ikan mempunyai kepentingan pada dua aspek, yaitu kebutuhan konsumtif yang tergantung pada metabolisme ikan dan kebutuhan lingkungan bagi spesies tertentu. Organisme air membutuhkan oksigen guna pembakaran bahan bakarnya (makanan) untuk menghasilkan aktivitas, seperti berenang, pertumbuhan, reproduksi, dan sebaliknya. Oleh karena itu, ketersediaan oksigen bagi organisme air menentukan lingkaran aktivitasnya, konversi pakan, dan laju pertumbuhan. 
Berdasarkan penelitian yang dilakukan, pengukuran DO dilakukan 2 kali sehari yaitu pada pagi hari pukul 09.00 dan sore hari pukul 16.00. berdasarkan hasil pengukuran yang dilakukan didapatkan nilai DO pada minggu pertama pagi hari berkisar 3,09-3,46 mg/L dan sore hari berkisar 2,89-3,04 mg/L. Selanjutnya nilai DO pada minggu kedua pagi hari berkisar 3,14-3,71 $\mathrm{mg} / \mathrm{L}$ dan sore hari berkisar 2,88-3,10 mg/L. Selanjutnya nilai DO minggu ketiga pagi hari berkisar $3,10-3,51 \mathrm{mg} / \mathrm{L}$ dan sore hari berkisar 2,91-3,15 mg/L. Selanjutnya nilai DO minggu keempat pagi hari berkisar 3,00$3,71 \mathrm{mg} / \mathrm{L}$ dan sore hari berkisar 2,95-3,01 $\mathrm{mg} / \mathrm{L}$.

\section{Pertumbuhan ikan}

Pertumbuhan adalah perubahan baik bobot maupun panjang dalam kurun waktu tertentu. Bobot tubuh dan panjang ikan dapat mengalami kenaikan namun juga dapat mengalami penurunan tergantung kondisi lingkungan. Berat ikan mengalami kenaikan apabila berada pada kondisi lingkungan yang disukai serta tersedia kelimpahan bahan makanan. Namun kondisi lingkungan yang buruk, seperti tingginya konsentrasi amoniak dan nitrit pada media pemeliharaan, dapat menjadi cekaman bagi ikan sehingga berat tubuh dapat mengalami penurunan. Penggunaan pakan yang sesuai juga menyebabkan pertumbuhan yang baik. Menurut Ahmadi et al., (2012) menyatakan bahwa pertumbuhan adalah pertambahan ukuran panjang atau berat dalam satuan waktu yang dipengaruhi oleh beberapa faktor, seperti keturunan, umur, parasit, pakan, dan kondisi perairan.

Berdasarkan hasil pengkuran yang tertera pada tabel 10 dan 11, dapat diketahui bahwa ikan uji yaitu ikan lele mengalami pertumnuhan panjang tubuh maupun bobotnya, bisa dilihat rata-rata ikan uji awalnya memiliki panjang sebesar 5,3 cm setelah 4 minggu pemeliharaan didapatkan pertumbuhan panjang rata-rata 6,1-7,8 cm, sedangkan bobot ikan uji awalnya memeiliki bobot sebesar 1,15 gram setelah 4 minngu pemeliharaan didapatkan penambahan bobot ikan sebesar rata-rata 1,13-3,89 gram.

\section{KESIMPULAN}

Kesimpulan yang dapat diambil dari penelitian Pengaruh Ekoenzim Terhadap Kualitas Air dalam Pembesaran Ikan Lele (Clarias sp)adalah sebagai berikut:

Berdasarkan hasil analisis data yang telah dilakukan pemberian ekoenzim dengan konsentrasi berbeda menunjukan bahwa tidak berpengaruh terhadap hasil konsentrasi amoniak dan nitrit dalam media pemeliharaan. Sedangkan untuk parameter $\mathrm{DO}, \mathrm{pH}$, dan temperatur berdasarkan hasil analisis secara deskriptif menyimpulkan bahwa walaupun kualitas air selama penelitian masih tergolong baik untuk budidaya dan kelangsungan hidup ikan lele, namun kualitas airnya masih kurang baik untuk masa pertumbuhan ikan lele sehingga membuat pertumbuhan ikan uji menjadi lambat.

Berdasarkan hasil penelitian yang telah dilakukan dapat diketahui dosis terbaik dalam penggunaan ekoenzim dipembesaran ikan lele yaitu $0,1 \mathrm{mg} / \mathrm{L}-1 \mathrm{mg} / \mathrm{L}$.

\section{UCAPAN TERIMAKASIH}

Penulis mengucapkan terimakasih kepada Prof.Dr.Ir. Djoko suprapto, DEA dan Dr.Ir.Haeruddin,M.Si yang telah ikut berkontribusi dalam penelitian ini.

\section{DAFTAR PUSTAKA}

Ahmadi, H. Iskandar, dan Nia K. 2012. Pemberian Probiotik Dalam Pakan Terhadap Pertumbuhan Ikan Lele Sangkuriang (Clarias gariepinus) Pada Pendederan II. Jurnal Perikanan dan Kelautan. 3(4) :99-107

Dewi. M.A, Rina.A, dan Yessy.A.N.2015. Uji Aktivitas Antibakteri Ekoenzim Terhadap Escherichia coli Dan Shigella dysenteriae.Seminar Nasional farmasi.2(1):60-68

Effendi, H. 2003. Telaah kualitas Air. Kanisius. Yogyakarta. 258 hlm.

Hastuti, S. dan Subandiyono. 2015. Kondisi Kesehatan Ikan Lele Dumbo (Clarias gariepinus) yang Dipelihara dengan Teknologi Biofloc. Jurnal Saintek Perikanan. 10(2): 74-79

Hermawan, A. T, Iskandar, dan Ujung. S. 2012. PengaruhPadat Tebar Terhadap Kelangsungan Hidup Pertumbuhan Lele Dumbo (Clarias gariepinus Burch) di Kolam Kali Menir Indramayu. Jurnal perikanan dan kelautan. 3(3): $85-93$

Iswandi, F. S. Afdal El-Rahimi, dan Iwan H. 2016. Pemanfaatan Limbah Budidaya Ikan Lele (Clarias gariepinus) Sebagai Pakan Alami Ikan Peres (Osteochillus sp.) Pada Sistem Resirkulasi. Jurnal Ilmiah Mahasiswa Kelautan dan Perikanan Unsyah. 1(3): 307-317

Kordi, K. M. G. dan A. B. Tancung. 2007. Pengelolaan Kualitas Air. Rineka Cipta, Jakarta,121 
Rachmawati. D, I. Samidjan, dan Heryoso. S. 2015. Manajemen Kualitas Air Media Budidaya Ikan Lele Sangkuriang (Clarias Gariepinus) Dengan Teknik Probiotik Pada Kolam Terpal Di Desa Vokasi Reksosari, Kecamatan Suruh, Kabupaten Semarang.P ena Akuatika. 12(1): 30 hlm

Tania, S. A. 2016. Dinamika Perubahan Kualitas Air Terhadap Pertumbuhan Ikan Lele Dumbo (Clarias gariepinus) yang Dipelihara di Kolam Tanah. Jurnal Ilmu Hewan Tropika. 5(1): 41-44

\section{Lampiran}

Tabel 1. Hasil Pengukuran Kualitas Air Minggu Pertama

\begin{tabular}{|c|c|c|c|c|c|}
\hline \multirow{2}{*}{ No } & \multirow{2}{*}{ Kode Sampel } & \multirow{2}{*}{ Jam } & \multicolumn{3}{|c|}{ Variabel } \\
\hline & & & $\mathrm{DO}(\mathrm{mg} / \mathrm{L})$ & Temperatur $\left({ }^{\circ} \mathrm{C}\right)$ & $\mathrm{pH}$ \\
\hline \multirow{2}{*}{1} & \multirow{2}{*}{ K1 ( Kontrol ) } & 09.00 & $3,09-3,56$ & $25,1-26,2$ & $5,61-6,15$ \\
\hline & & 16.00 & $2,89-3,05$ & $25,0-26,0$ & $5,89-6,16$ \\
\hline \multirow{2}{*}{2} & \multirow{2}{*}{ K2 ( Kontrol ) } & 09.00 & $3,17-3,71$ & $25,2-26,4$ & $5,81-6,25$ \\
\hline & & 16.00 & $2,91-3,01$ & $25,1-26,0$ & $5,99-6,21$ \\
\hline \multirow{2}{*}{3} & \multirow{2}{*}{ K3 ( Kontrol ) } & 09.00 & $3,21-3,61$ & $25,2-26,2$ & $5,99-6,35$ \\
\hline & & 16.00 & $2,87-3,01$ & $25,0-26,1$ & $6,00-6,21$ \\
\hline \multirow{2}{*}{4} & \multirow{2}{*}{ A1 ( 0,1 mg/L) } & 09.00 & $3,30-3,62$ & $25,1-26,2$ & $5,60-6,05$ \\
\hline & & 16.00 & $2,81-3,07$ & $25,0-26,0$ & $5,89-6,01$ \\
\hline \multirow{2}{*}{5} & \multirow{2}{*}{$\mathrm{A} 2(0,1 \mathrm{mg} / \mathrm{L})$} & 09.00 & $3,07-3,57$ & $25,6-26,1$ & $5,75-6,24$ \\
\hline & & 16.00 & $2,85-3,01$ & $25,3-26,0$ & $5,99-6,15$ \\
\hline \multirow{2}{*}{6} & \multirow{2}{*}{ A3 ( 0,1 mg/L) } & 09.00 & $3,15-3,63$ & $25,3-26,1$ & $5,21-6,89$ \\
\hline & & 16.00 & $2,81-3,01$ & $25,1-26,0$ & $5,96-6.65$ \\
\hline \multirow{2}{*}{7} & \multirow{2}{*}{ B1 ( 0,5 mg/L ) } & 09.00 & $3,17-3,51$ & $25,7-26,3$ & $5,60-6,07$ \\
\hline & & 16.00 & $2,81-3,01$ & $25,1-26,0$ & $5,81-6,11$ \\
\hline \multirow{2}{*}{8} & \multirow{2}{*}{ B2 $(0,5 \mathrm{mg} / \mathrm{L})$} & 09.00 & $3,10-3,51$ & $25,0-26,2$ & $5,95-6,35$ \\
\hline & & 16.00 & $2,83-2,99$ & $25,0-26,0$ & $5,99-6,15$ \\
\hline \multirow{2}{*}{9} & \multirow{2}{*}{ B3 $(0,5 \mathrm{mg} / \mathrm{L})$} & 09.00 & $3,10-3,51$ & $25,2-26,0$ & $5,21-6,21$ \\
\hline & & 16.00 & $2,87-3,00$ & $25,0-26,0$ & $5,89-6,10$ \\
\hline \multirow{2}{*}{10} & \multirow{2}{*}{$\mathrm{C} 1 \quad(1 \mathrm{mg} / \mathrm{L})$} & 09.00 & $3,09-3,51$ & $25,1-26,1$ & $5,25-6,21$ \\
\hline & & 16.00 & $2,84-3,00$ & $25,1-26,1$ & $5,43-6,16$ \\
\hline \multirow{2}{*}{11} & \multirow{2}{*}{$\mathrm{C} 2(1 \mathrm{mg} / \mathrm{L})$} & 09.00 & $3,10-3,38$ & $25,0-26,1$ & $5,93-6,30$ \\
\hline & & 16.00 & $2,88-3,00$ & $25,0-26,0$ & $5,87-6,03$ \\
\hline \multirow{2}{*}{12} & \multirow{2}{*}{ C3 ( $1 \mathrm{mg} / \mathrm{L})$} & 09.00 & $3,10-3,41$ & $25,1-26,3$ & $5,96-6,25$ \\
\hline & & 16.00 & $2,91-3,00$ & $25,0-26,0$ & $5,83-6,10$ \\
\hline
\end{tabular}

Tabel 2. Hasil Pengukuran Kualitas Air Minggu Kedua

\begin{tabular}{|c|c|c|c|c|c|}
\hline \multirow{2}{*}{ No } & \multirow{2}{*}{ Kode Sampel } & \multirow{2}{*}{ Jam } & \multicolumn{3}{|c|}{ Variabel } \\
\hline & & & $\mathrm{DO}(\mathrm{mg} / \mathrm{L})$ & Temperatur $\left({ }^{\circ} \mathrm{C}\right)$ & $\mathrm{pH}$ \\
\hline \multirow{2}{*}{1} & \multirow{2}{*}{ K1 ( Kontrol ) } & 09.00 & $3,21-3,41$ & $25,5-26,3$ & $5,80-6,16$ \\
\hline & & 16.00 & $2,91-3,01$ & $25,1-26,1$ & $5,99-6,05$ \\
\hline \multirow{2}{*}{2} & \multirow{2}{*}{ K2 ( Kontrol ) } & 09.00 & $3,09-3,53$ & $25,9-26,1$ & $5,88-6,31$ \\
\hline & & 16.00 & $2,81-3,01$ & $25,6-26,1$ & $5,85-6,11$ \\
\hline \multirow{2}{*}{3} & \multirow{2}{*}{ K3 ( Kontrol ) } & 09.00 & $3,18-3,51$ & $25,9-26,3$ & $5,79-6,17$ \\
\hline & & 16.00 & $2,89-3,05$ & $25,8-26,0$ & $5,90-6,15$ \\
\hline 4 & $\mathrm{~A} 1(0,1 \mathrm{mg} / \mathrm{L})$ & 09.00 & $3,11-3,51$ & $25,9-26,1$ & $5,79-6,18$ \\
\hline
\end{tabular}




\begin{tabular}{|c|c|c|c|c|c|}
\hline \multirow{3}{*}{5} & \multirow{3}{*}{$\mathrm{A} 2(0,1 \mathrm{mg} / \mathrm{L})$} & 16.00 & $2,71-3,02$ & $25,8-26,0$ & $5,99-6,19$ \\
\hline & & 09.00 & $3,07-3,42$ & $25,8-26,1$ & $6,05-6,93$ \\
\hline & & 16.00 & $2,78-3,01$ & $25,6-26,0$ & $6,00-6,31$ \\
\hline \multirow{2}{*}{6} & \multirow{2}{*}{ A3 ( 0,1 mg/L) } & 09.00 & $3,09-3,44$ & $25,8-26,1$ & $5,83-6,27$ \\
\hline & & 16.00 & $2,75-3,01$ & $25,9-26,1$ & $6,00-6,28$ \\
\hline \multirow{2}{*}{7} & \multirow{2}{*}{ B1 $(0,5 \mathrm{mg} / \mathrm{L})$} & 09.00 & $3,10-3,47$ & $25,8-26,0$ & $5,84-6,17$ \\
\hline & & 16.00 & $2,88-3,00$ & $25,7-26,0$ & $5,99-6,15$ \\
\hline \multirow{2}{*}{8} & \multirow{2}{*}{ B2 $(0,5 \mathrm{mg} / \mathrm{L})$} & 09.00 & $3,10-3,59$ & $25,9-26,1$ & $5,77-6,14$ \\
\hline & & 16.00 & $2,81-2,99$ & $25,7-26,0$ & $5,87-6,25$ \\
\hline \multirow{2}{*}{9} & \multirow{2}{*}{ B3 $(0,5 \mathrm{mg} / \mathrm{L})$} & 09.00 & $3,11-3,51$ & $25,8-26,3$ & $5,79-6,10$ \\
\hline & & 16.00 & $2,90-3,01$ & $25,8-26,0$ & $5,77-6,15$ \\
\hline \multirow{2}{*}{10} & \multirow[t]{2}{*}{ C1 ( $1 \mathrm{mg} / \mathrm{L})$} & 09.00 & $3,12-3,52$ & $25,8-26,1$ & $5,79-6,15$ \\
\hline & & 16.00 & $2,84-3,00$ & $25,6-26,0$ & $5,85-6,10$ \\
\hline \multirow{2}{*}{11} & \multirow{2}{*}{$\mathrm{C} 2(1 \mathrm{mg} / \mathrm{L})$} & 09.00 & $3,20-3,51$ & $25,9-26,1$ & $5,79-6,11$ \\
\hline & & 16.00 & $2,82-3,01$ & $25,6-26,0$ & $5,99-6,10$ \\
\hline \multirow{2}{*}{12} & \multirow{2}{*}{ C3 ( $1 \mathrm{mg} / \mathrm{L})$} & 09.00 & $3,09-3,43$ & $25,8-26,0$ & $5,83-6,18$ \\
\hline & & 16.00 & $2,89-3,01$ & $25,8-26,0$ & $5,90-6,20$ \\
\hline
\end{tabular}

Tabel 3. Hasil Pengukuran Kualitas Air Minggu Ketiga

\begin{tabular}{|c|c|c|c|c|c|}
\hline \multirow{2}{*}{ No } & \multirow{2}{*}{ Kode Sampel } & \multirow{2}{*}{ Jam } & \multicolumn{3}{|c|}{ Variabel } \\
\hline & & & $\mathrm{DO}(\mathrm{mg} / \mathrm{L})$ & Temperatur $\left({ }^{\circ} \mathrm{C}\right)$ & $\mathrm{pH}$ \\
\hline \multirow{2}{*}{1} & \multirow{2}{*}{ K1 ( Kontrol ) } & 09.00 & $3,21-3,51$ & $25,5-26,3$ & $5,99-6,21$ \\
\hline & & 16.00 & $2,81-3,06$ & $25,6-26,1$ & $6,00-6,17$ \\
\hline \multirow{2}{*}{2} & \multirow{2}{*}{ K2 ( Kontrol ) } & 09.00 & $3,07-3,41$ & $25,9-26,4$ & $5,99-6,11$ \\
\hline & & 16.00 & $2,71-3,00$ & $25,7-26,0$ & $5,95-6,15$ \\
\hline \multirow{2}{*}{3} & \multirow{2}{*}{ K3 ( Kontrol ) } & 09.00 & $3,09-3,63$ & $25,9-26,1$ & $6,00-6,14$ \\
\hline & & 16.00 & $2,72-3,01$ & $25,8-25,9$ & $5,99-6,15$ \\
\hline \multirow{2}{*}{4} & \multirow{2}{*}{ A1 ( $0,1 \mathrm{mg} / \mathrm{L})$} & 09.00 & $3,11-3,35$ & $25,8-26,1$ & $5,99-6,11$ \\
\hline & & 16.00 & $2,91-3,00$ & $25,7-25,9$ & $5,78-6,11$ \\
\hline \multirow{2}{*}{5} & \multirow{2}{*}{$\mathrm{A} 2(0,1 \mathrm{mg} / \mathrm{L})$} & 09.00 & $3,07-3,38$ & $25,6-26,1$ & $6,00-6,11$ \\
\hline & & 16.00 & $2,78-3,01$ & $25,4-26,0$ & $5,99-6,21$ \\
\hline \multirow{2}{*}{6} & \multirow{2}{*}{ A3 ( 0,1 mg/L) } & 09.00 & $3,10-3,51$ & $25,6-26,1$ & $5,87-6,11$ \\
\hline & & 16.00 & $2,76-3,00$ & $25,2-26,0$ & $5,99-6,17$ \\
\hline \multirow{2}{*}{7} & \multirow{2}{*}{ B1 ( 0,5 mg/L ) } & 09.00 & $3,11-3,51$ & $25,7-26,0$ & $5,97-6,14$ \\
\hline & & 16.00 & $2,84-3,00$ & $25,7-26,0$ & $5,90-6,16$ \\
\hline \multirow{2}{*}{8} & \multirow{2}{*}{ B2 $(0,5 \mathrm{mg} / \mathrm{L})$} & 09.00 & $3,09-3,43$ & $25,7-26,1$ & $5,87-6,14$ \\
\hline & & 16.00 & $2,70-3,01$ & $25,8-25,9$ & $5,86-6,05$ \\
\hline \multirow{2}{*}{9} & \multirow{2}{*}{ B3 $(0,5 \mathrm{mg} / \mathrm{L})$} & 09.00 & $3,10-3,38$ & $25,9-26,0$ & $5,79-6,07$ \\
\hline & & 16.00 & $2,79-3,00$ & $25,8-26,0$ & $5,87-6,12$ \\
\hline \multirow{2}{*}{10} & \multirow{2}{*}{$\mathrm{C} 1(1 \mathrm{mg} / \mathrm{L})$} & 09.00 & $3,14-3,51$ & $25,7-26,0$ & $5,88-6,21$ \\
\hline & & 16.00 & $2,71-3,02$ & $25,7-26,0$ & $5,99-6,17$ \\
\hline \multirow{2}{*}{11} & \multirow{2}{*}{$\mathrm{C} 2(1 \mathrm{mg} / \mathrm{L})$} & 09.00 & $3,07-3,41$ & $25,9-26,0$ & $5,91-6,17$ \\
\hline & & 16.00 & $2,75-3,00$ & $25,9-26,0$ & $5,79-6,11$ \\
\hline \multirow{2}{*}{12} & \multirow{2}{*}{$\mathrm{C} 3(1 \mathrm{mg} / \mathrm{L})$} & 09.00 & $3,09-3,57$ & $25,9-26,0$ & $5,90-6,09$ \\
\hline & & 16.00 & $2,81-3,01$ & $25,9-26,0$ & $5,86-6,07$ \\
\hline
\end{tabular}


Tabel 4. Hasil Pengukuran Kualitas Air Minggu Keempat

\begin{tabular}{|c|c|c|c|c|c|}
\hline \multirow{2}{*}{ No } & \multirow{2}{*}{ Kode Sampel } & \multirow{2}{*}{ Jam } & \multicolumn{3}{|c|}{ Variabel } \\
\hline & & & $\mathrm{DO}(\mathrm{mg} / \mathrm{L})$ & Temperatur $\left({ }^{\circ} \mathrm{C}\right)$ & $\mathrm{Ph}$ \\
\hline \multirow{2}{*}{1} & \multirow{2}{*}{ K1 ( Kontrol ) } & 09.00 & $3,09-3,51$ & $25,7-26,2$ & $5,80-6,15$ \\
\hline & & 16.00 & $2,81-3,01$ & $25,6-25,9$ & $5,93-6,16$ \\
\hline \multirow{2}{*}{2} & \multirow{2}{*}{ K2 ( Kontrol ) } & 09.00 & $3,07-3,71$ & $25,7-26,1$ & $5,81-6,25$ \\
\hline & & 16.00 & $2,89-3,00$ & $25,6-26,1$ & $5,85-6,11$ \\
\hline \multirow{2}{*}{3} & \multirow{2}{*}{ K3 ( Kontrol ) } & 09.00 & $3,09-3,63$ & $25,7-26,3$ & $5,79-6,15$ \\
\hline & & 16.00 & $2,72-3,01$ & $25,6-26,0$ & $5,90-6,11$ \\
\hline \multirow{2}{*}{4} & \multirow{2}{*}{ A1 ( 0,1 mg/L) } & 09.00 & $3,07-3,41$ & $25,7-26,3$ & $5,60-6,01$ \\
\hline & & 16.00 & $2,87-3,00$ & $25,7-26,0$ & $5,78-6,07$ \\
\hline \multirow{2}{*}{5} & \multirow{2}{*}{$\mathrm{A} 2(0,1 \mathrm{mg} / \mathrm{L})$} & 09.00 & $3,09-3,57$ & $25,6-26,1$ & $5,99-6,24$ \\
\hline & & 16.00 & $2,78-3,01$ & $25,6-26,0$ & $5,91-6,13$ \\
\hline \multirow{2}{*}{6} & \multirow{2}{*}{ A3 ( 0,1 mg/L) } & 09.00 & $3,10-3,63$ & $25,6-26,1$ & $5,90-6,89$ \\
\hline & & 16.00 & $2,79-3,01$ & $25,5-26,1$ & $5,99-6,65$ \\
\hline \multirow{2}{*}{7} & \multirow{2}{*}{ B1 ( 0,5 mg/L ) } & 09.00 & $3,11-3,51$ & $25,6-26,0$ & $5,81-6,07$ \\
\hline & & 16.00 & $2,83-3,00$ & $25,6-25,9$ & $5,99-6,11$ \\
\hline \multirow{2}{*}{8} & \multirow{2}{*}{ B2 $(0,5 \mathrm{mg} / \mathrm{L})$} & 09.00 & $3,10-3,51$ & $25,2-26,0$ & $5,71-6,05$ \\
\hline & & 16.00 & $2,70-3,01$ & $25,5-25,9$ & $5,81-6,11$ \\
\hline \multirow{2}{*}{9} & \multirow{2}{*}{ B3 $(0,5 \mathrm{mg} / \mathrm{L})$} & 09.00 & $3,10-3,38$ & $25,2-26,3$ & $5,74-6,11$ \\
\hline & & 16.00 & $2,81-2,99$ & $25,5-26,0$ & $5,77-6,17$ \\
\hline \multirow{2}{*}{10} & \multirow{2}{*}{$\mathrm{C} 1 \quad(1 \mathrm{mg} / \mathrm{L})$} & 09.00 & $3,12-3,51$ & $25,9-26,1$ & $5,25-6,07$ \\
\hline & & 16.00 & $2,81-2,99$ & $25,8-26,0$ & $5,44-6,01$ \\
\hline \multirow{2}{*}{11} & \multirow{2}{*}{$\mathrm{C} 2(1 \mathrm{mg} / \mathrm{L})$} & 09.00 & $3,08-3,41$ & $25,9-26,2$ & $5,93-6,01$ \\
\hline & & 16.00 & $2,76-2,99$ & $25,7-26,0$ & $5,87-6,10$ \\
\hline \multirow{2}{*}{12} & \multirow{2}{*}{ C3 ( $1 \mathrm{mg} / \mathrm{L})$} & 09.00 & $3,10-3,57$ & $25,9-26,1$ & $5,83-6,00$ \\
\hline & & 16.00 & $2,89-3,01$ & $25,7-26,1$ & $5,83-6,10$ \\
\hline
\end{tabular}

